\title{
Dietary education among patients following coronary artery bypass surgery - a necessity or an unnecessary luxury?
}

\author{
Elżbieta Szczepańska, Malwina Brodzikowska, Beata Całyniuk \\ Department of Human Nutrition, Faculty of Public Health, Medical University of Silesia, Zabrze
}

Kardiochirurgia i Torakochirurgia Polska 2014; 11 (1): 12-16

\begin{abstract}
Introduction: Despite rapid progress in cardiology and cardiac surgery, cardiovascular disease still present a serious epidemiological problem in industrialized countries, including Poland. Great interest in risk factors of these diseases is associated with an improper lifestyle, including diet.

Aim of the study: We aimed to assess the dietary intake among patients with a history of coronary artery bypass (CABG) surgery and to determine whether a regular dietary education among this population of patients is necessary.

Material and methods: 212 patients with a history of CABG surgery were enrolled in the study. A questionnaire concerning the diet within 24 hours prior to the visit was used to obtain the necessary data.

Results: $43 \%$ of patients ate 4 to 5 servings per day. Milk was consumed most often several times per week or once every day. Meat consumption several times per week was reported by $41 \%$ of patients. $54 \%$ of patients reported eating fish several times per month. Half of the patients ate several servings of vegetables per day. $84 \%$ of patients used salt and other spices to season their meals. The energy value and the intake of protein, fats, carbohydrates and fiber was lower, while sodium intake was higher, than recommended for this group of patients. Conclusions: Patients with a history of CABG have an unhealthy diet, and do not follow the dietary guidelines. It is necessary to carry out systematic nutrition education among this group. Key words: dietary education, CABG patients, nutrition.
\end{abstract}

\section{Introduction}

Despite the rapid progress in cardiology and cardiac surgery, cardiovascular disease continues to pose a serious

\section{Streszczenie}

Wstęp: Pomimo dużego postępu, jaki dokonał się w kardiologii i kardiochirurgii, choroby układu sercowo-naczyniowego nadal stanowią poważny problem epidemiologiczny w krajach uprzemysłowionych, także w Polsce. Powoduje to coraz większe zainteresowanie czynnikami ryzyka tych chorób związanymi z niewłaściwym stylem życia, w tym także sposobem odżywiania. Celem pracy jest ocena sposobu żywienia w grupie pacjentów po operacji pomostowania aortalno-wieńcowego (CABG) oraz odpowiedź na pytanie, czy konieczne jest prowadzenie systematycznej edukacji żywieniowej w tej grupie osób.

Materiat i metody: Badaniem objęto 212 osób, u których wykonano zabieg pomostowania aortalno-wieńcowego. Do zebrania danych posłużyła ankieta oraz kwestionariusz badający spożycie produktów w ciągu 24 godzin przed wizytą.

Wyniki: Zalecane 4-5 posiłków dziennie spożywało $43 \%$ badanych. Mleko było spożywane najczęściej kilka razy w tygodniu oraz raz dziennie. Mięso kilka razy w tygodniu spożywało $41 \%$ badanych osób. 54\% pacjentów deklarowało jedzenie ryb kilka razy w miesiącu. Połowa uczestniczących w badaniu spożywała warzywa kilka razy dziennie. 84\% badanych osób używało soli i/lub innych przypraw do przyrządzania potraw. Średnia wartość energetyczna, zawartość białka, tłuszczów, węglowodanów i błonnika w spożywanych posiłkach była niższa, a zawartość sodu wyższa niż wskazują zalecenia dla tej grupy pacjentów.

Wnioski: Sposób żywienia pacjentów po operacjach pomostowania aortalno-wieńcowego jest nieprawidłowy; występują w nim odchylenia od zaleceń żywieniowych. Konieczne jest prowadzenie systematycznej edukacji żywieniowej wśród tej grupy. Słowa kluczowe: edukacja żywieniowa, pacjenci kardiologiczni, odżywianie.

epidemiological problem in industrialized countries (including Poland), with high mortality and morbidity rates [1]. A report on the health status of the population of Poland was published in 2009. Experts list arterial hypertension

Address for correspondence: dr n. med. Elżbieta Szczepańska, Department of Human Nutrition, Faculty of Public Health, Medical University of Silesia, 19 Jordana Str., 41-808 Zabrze, phone: +48 3227551 97, e-mail: eszczepanska@sum.edu.pl 
and coronary artery disease among the five most prevalent chronic diseases. These alarming data raise awareness and public interest in risk factors, especially lifestyle, associated with these diseases, as well as in preventive measures $[2,3]$. These lifestyle interventions make it possible not only to reduce mortality and morbidity, but also to improve the quality of life [4-6]. Our primary objective was to assess the dietary intake among patients with a history of coronary artery bypass (CABG) surgery. The second objective was to determine whether a regular dietary education among this population of patients is necessary.

\section{Material and methods}

Two hundred and twelve patients (89 women and 123 men with a mean age of 64.3 years) with a history of CABG surgery were enrolled in the study. The patients underwent CABG surgery 12-36 months prior to the study and were seen in the outpatient cardiology clinic. Baseline characteristics are presented in Table I. Arterial hypertension was diagnosed in $71 \%$ of patients, type 2 diabetes mellitus in $28.5 \%$ of patients and hypercholesterolemia in $47 \%$ of patients.

A special questionnaire concerning the diet within 24 hours prior to the visit was used to obtain the necessary data. It consisted of two parts:

- part one included questions about the socioeconomic status (age, education, professional activity), the medical status (blood pressure values, cholesterol level), and anthropometrics (height, weight, body-mass index),

- part two included questions about the dietary habits and the frequency of intake of products from each group of food products.
Food intake assessment was carried out according to the standards set by the National Food and Nutrition Institute. Determination of the size of food rations, as well as their qualitative and quantitative evaluation, was performed with the "Photo Album of Products and Dishes" developed at the National Food and Nutrition Institute. This album contains a list of the most frequent food products and dishes encountered in everyday diet [7].

Continuous variables are reported as means \pm standard deviation (SD). Categorical variables are expressed as counts and percentages. An unpaired $t$-test was used to compare the gender differences in caloric and nutritional values. A two-sided $p$-value $\leq 0.05$ was considered significant. For all calculations, STATISTICA 7.1 software was used.

\section{Results}

\section{Dietary habits}

$43 \%$ of patients (50\% of men and $34 \%$ of women) ate 4 to 5 servings per day as recommended. The majority of patients ate mixed-grain bread (48\%) with a similar rate in men (49\%) and women (46\%). Milk was consumed most often several times per week (no gender differences) or once every day (more men indicated this answer). 11\% of patients did not drink milk at all. The largest group of patients (55\%) consumed cultured dairy products several times per week (56\% of men and $53 \%$ of women). $5 \%$ of patients did not eat these products at all. $41 \%$ of patients ate several servings of cottage cheese per week and $26 \%$ of patients ate several servings per month (more men [29\%] than women [22\%]). $5 \%$ of patients did not eat cottage cheese at all. $54 \%$ of patients ate several servings of hard

Tab. I. Baseline characteristics

\begin{tabular}{l}
\multicolumn{3}{c}{ Women } \\
\cline { 2 - 6 } \\
\cline { 2 - 6 }
\end{tabular}


cheese and processed cheese per week (more men [57\%] than women [49\%]). $3 \%$ of patients did not eat these types of cheese at all. Meat consumption several times per week was reported by $41 \%$ of patients $(43 \%$ of men and $39 \%$ of women). One third of patients ate meat once every day (more men than women). The analysis showed that most patients (44\%) ate various types of meat, whereas $25 \%$ of patients chose poultry and pork (more women than men in both instances). 54\% of patients reported eating fish several times per month (similar rates among both genders), while $25 \%$ of patients reported eating fish several times a week (27\% of men and $23 \%$ of women). As to fat intake, the largest group of patients (45\%) reported using soft tub margarine (similar rates among men [46\%] and women [44\%]). $56 \%$ of patients used vegetable oil for frying. Half of the patients ate several servings of vegetables per day ( $44 \%$ of men and $59 \%$ of women). We were concerned about the fact that $25 \%$ of patients (similar rates among both genders) ate only several servings of vegetables per week. $44 \%$ of patients ate one serving of fruit per day $(43 \%$ in men and $47 \%$ in women), whereas $25 \%$ of patients ate several servings of fruit per day (more men [27\%] than women [19\%]). $84 \%$ of patients used salt and other spices to season their meals (similar rates among both genders).

\section{Assessment of the nutritional value of the menus}

Gender-wise comparison of the nutritional value of the menus is presented in Table II. The mean energy value and the intake of protein, fats, carbohydrates and fiber were lower (both in men and women) than recommended for this group of patients. Sodium intake was higher than recommended and men consumed more sodium than women. There was a gender-wise statistical difference between energy and nutritional values for protein, cholesterol, sodium and potassium intake.

\section{Discussion}

Unhealthy diet remains one of the major cardiovascular risk factors. Pharmacotherapy and lifestyle modification, including a proper diet, remain essential interventions in the secondary prevention of cardiovascular disease.

According to the dietary guidelines, patients with cardiovascular disease should eat 4 to 5 meals per day. We found that half of the patients ate only 3 meals per day and only $43 \%$ of patients ate the recommended 4 to 5 meals per day. Piórecka et al. obtained similar results, when they analyzed the influence of the diet on the prevalence of cardiovascular risk factors among female inhabitants of Cracow. Fifty-one percent of women ate only 3 meals per day [8]. Charbos et al. analyzed the lifestyle of women aged 70 years or older. They found that $42 \%$ of them ate 4 meals per day, while $23 \%$ of them ate 5 meals per day [9].

Whole-grain cereal bread is an important element of everyday diet that provides us with carbohydrates, macroelements and fiber. Studied patients ate mixed-grain bread most often and only $20 \%$ of patients ate whole-grain cereal bread. Król et al. reported more favorable results. They analyzed 200 patients with cardiovascular disease and found that $41 \%$ of patients ate mixed-grain bread, $31 \%$ of patients ate white bread and $28 \%$ of patients ate brown bread [10].

Milk, cheese and other dairy products are recommended in cardiovascular disease, provided they are low in fat. They are a major source of protein and calcium, which participates in the regulation of blood pressure. We found that $30 \%$ of studied patients drank several servings of milk per week, while $29 \%$ of patients drank one serving of milk once per day. Fifty-five percent of patients ate several servings of cultured dairy products per week. Pawelec et al. observed more favorable dietary habits in 100 patients hospitalized in the Department of Cardiac Surgery in Szczecin. They reported that $61 \%$ of patients drank or ate several servings of milk or other dairy products per day. Thirty-five percent of patients ate at least one serving of dairy products per day [11].

Meat and meat products are an essential element of the diet in cardiovascular disease. They are a primary source of full-fledged protein, but also contain a significant amount of animal fat and, therefore, cholesterol. In our study, we found that $41 \%$ of patients ate several servings of meat for dinner per week and almost one third of the

Tab. II. Nutritional value of the menus

\begin{tabular}{|c|c|c|c|c|c|c|c|}
\hline \multirow{2}{*}{ Energy and nutrients } & \multicolumn{3}{|c|}{ Women } & \multicolumn{3}{|c|}{ Men } & \multirow{2}{*}{$p^{*}$} \\
\hline & Mean \pm SD & Min. & Max. & Mean \pm SD & Min. & Max. & \\
\hline Energy [kcal] & $1451.7 \pm 591.3$ & 268.5 & 3767 & $1606.1 \pm 664.3$ & 455.5 & 5491.2 & 0.084 \\
\hline Protein [g] & $49.3 \pm 49.3$ & 0.63 & 111.0 & $58.9 \pm 22.6$ & 16.5 & 195.2 & 0.002 \\
\hline Fats [g] & $55.6 \pm 37.4$ & 2.1 & $272, .2$ & $63.9 \pm 45.2$ & 9.3 & 404.0 & 0.164 \\
\hline Cholesterol [mg] & $171.1 \pm 118.5$ & 4.0 & 558.0 & $229.1 \pm 159.7$ & 25.0 & 1047.0 & 0.004 \\
\hline Carbohydrates [g] & $188.5 \pm 78.4$ & 28.9 & 412.7 & $198.9 \pm 77.7$ & 51.3 & 427.8 & 0.343 \\
\hline Fiber [g] & $15.2 \pm 7.5$ & 1.7 & 54.3 & $16.6 \pm 7.9$ & 3.0 & 54.7 & 0.179 \\
\hline Sodium [mg] & $1381.7 \pm 778.9$ & 142.0 & 5002.0 & $1693.7 \pm 969.3$ & 522.0 & 8629.0 & 0.013 \\
\hline Potassium [mg] & $2261.1 \pm 1002.3$ & 266.0 & 5893.0 & $2715.7 \pm 1109.4$ & 781.0 & 6156.0 & 0.002 \\
\hline
\end{tabular}


patients ate a serving of meat for dinner on a daily basis. Król et al. reported that $55 \%$ of patients ate several servings of meat and meat products per week [10]. In our study, $45 \%$ of patients ate various types of meat. In turn, $25 \%$ of patients ate poultry. Król et al. reported that according to $90 \%$ of respondents declared the consumption of lean meats, while more than half of the respondents ate low-fat, smoked cold meat, and one third of the patients regularly ate high-fat meat [10]. Mędrela-Kuder et al. analyzed the dietary habits of 63 patients at the time of post-myocardial infarction rehabilitation. The consumption rate of low-fat poultry, high-fat poultry, pork and beef was 51\%, 33\%, 10\% and $6 \%$ respectively [12]. Pawelec et al., while analyzing 100 patients hospitalized in the Department of Cardiac Surgery, found that pork, beef and poultry were the preferred types of meat for $39 \%, 36 \%$ and $20 \%$ of patients respectively [11]. Waśkiewicz et al. studied the food quality and nutrition knowledge among Polish patients who had experienced a cardiovascular event and found that $49 \%$ of men and $32 \%$ of women ate meat with visible fat [13].

Oily fish containing unsaturated fatty acids, especially omega-3 acids, are the best alternative to meat. These substances have a favorable effect on the cardiovascular system. We found that $54 \%$ of patients ate several servings of fish per month, while $25 \%$ of patients ate several servings per week. Pawelec et al. presented disturbing data in that matter. They reported that $75 \%$ of patients did not eat fish at all [11]. On the other hand, Król et al. found that $47.5 \%$ of patients ate one serving of fish per week and $20 \%$ of patients ate several servings of fish per week [10]. Mojsa et al., who analyzed the lifestyles of patients with coronary artery disease, reported that $73 \%$ of patients ate one to several servings of fish per week [14].

Vegetable and animal fats are an essential part of an everyday diet. However, excessive intake of fats above the recommended levels leads to weight gain and hypercholesterolemia, thus contributing to atherogenesis. We found that $45 \%$ of patients used soft tub margarine to spread on bread and $18 \%$ of patients used butter. Mędrela-Kuder et al. presented disturbing data that $56 \%$ of patients used animal fats [12]. Król et al. reported that $62.5 \%$ of patients used soft tub margarine or butter to spread on bread [10]. Wierzbicka et al. studied the lifestyle of 50 patients with angina. They found that $29 \%$ of patients used animal butter to spread on bread, while $24 \%$ of patients used margarine [15].

Patients with cardiovascular disease should avoid fried foods. They should steam, broil, grill, roast or poach instead of frying. We found that $56 \%$ of patients fried food in vegetable oils and $22 \%$ of patients in margarines. Pawelec et al. reported that $23 \%$ of patients did not use any fat during frying. The fact that $34 \%$ of patients used lard and $30 \%$ of patients used vegetable oil raises concern [11]. Meanwhile, Król et al. found that $60 \%$ of patients used the recommended fats during frying [10].

Fruits and vegetables are an essential source of nutrients (vitamins, minerals, flavonoids and fiber). It is recommended that to maintain a healthy diet 4 to 5 servings of fruits and vegetables should be eaten on a daily basis. Many studies have confirmed that an adequate amount of fruits and vegetables (about $400 \mathrm{~g} /$ day) decreases the risk of myocardial infarction and stroke, lowers blood pressure, and helps overweight and obese patients to lose weight [16]. We found that $77 \%$ of patients ate vegetables every day and $67 \%$ of patients ate fruits every day. Pawelec et al. reported that $64 \%$ of patients ate at least one serving of fruits and vegetables per week [11]. Piotrowska et al. studied patients hospitalized in the Department of Cardiology. They found that $66 \%$ of patients ate 2 to 3 servings of fruits and vegetables per week [17]. Mojsa et al. reported that $76 \%$ of patients with coronary artery disease ate at least one serving of fruits and vegetables per day [14].

Sodium chloride adds a substantial risk to the development of hypertension. It is important to minimize or exclude added salt or other products high in sodium, since most sodium comes from salt, which - added during food processing - cannot be excluded. We found that $84 \%$ of patients added salt at the table and in cooking. Suliburska et al. analyzed the frequency of a low sodium diet among patients with hypertension. They found that $88 \%$ of patients added salt to food [18]. Zielińska-Więczkowska et al. studied 55 hypertensive patients hospitalized in the Department of Geriatrics in Bydgoszcz. The authors reported that $13 \%$ of patients used large amounts of salt [19]. Waśkiewicz et al. analyzed the dietary habits in patients with cardiovascular disease and found that $25 \%$ of men and $19 \%$ of women added salt at the table to dishes that were already seasoned [13]. A well-balanced diet helps the human body obtain the essential nutrients needed for proper functioning. This, in turn, results in positive health benefits. The recommended energy value, the appropriate nutrient content and the adequate number of meals throughout the day allow one to achieve or maintain a proper body weight. We found that the mean energy values of the daily menu were $1451.7 \pm 591.3 \mathrm{kcal} /$ day in women and $1606.1 \pm$ $664.3 \mathrm{kcal} / \mathrm{day}$ in men; the mean protein intake was $49.3 \mathrm{~g} /$ day and 58.9 g/day respectively; the mean fat intake was $55.6 \mathrm{~g} /$ day and $63.9 \mathrm{~g} /$ day respectively; and the mean cholesterol intake was $171.1 \mathrm{mg} /$ day and $229.1 \mathrm{mg} /$ day respectively. Suliburska et al. obtained similar results. They analyzed 37 patients with hypertension and found that the mean energy value was $1406 \mathrm{kcal} /$ day, the mean protein intake was $54 \mathrm{~g} /$ day, the mean fat intake was $58 \mathrm{~g} /$ day, whereas the mean cholesterol intake was $222 \mathrm{mg} /$ day [20]. Waśkiewicz et al. presented unfavorable results regarding the implementation of dietary guidelines in respect of the content of fat in the diet of patients with a history of cardiovascular events [13]. Others reported insufficient intake of carbohydrates and fiber in the diet $[8,18]$.

Our findings, along with those of others, lead us to believe that the prevalence of unhealthy dietary habits among patients with cardiovascular disease is high. All of these elements point to the necessity of forming new healthy eating patterns by providing education and nutritional 
counseling, which will help improve the treatment and patients' quality of life.

\section{Conclusions}

1. Patients after coronary artery bypass surgery have an unhealthy diet. The patients fail to follow the dietary guidelines.

2. It is necessary to provide systematic nutrition education and counseling to this group of patients.

\section{References}

1. Wojtyniak B, Goryński P (red.). Sytuacja zdrowotna ludności Polski. Narodowy Instytut Zdrowia Publicznego. PZH, Warszawa 2008.

2. WHO. The European health reports: public health action for healthier children and populations. WHO, Europe 2005.

3. WHO. Raport, Gaining Health, 2006.

4. Żebrowska A, Hryniewiecki T. Profilaktyka pierwotna i wtórna w chorobach układu krążenia. Nowa Klin 2009; 16: 311-320.

5. Jaxa-Chamiec T. Prewencja wtórna schorzeń sercowo-naczyniowych jako stały element kompleksowej rehabilitacji kardiologicznej. Post Nauk Med 2008; 10: 677-697.

6. Graham I, Atar D, Borch-Johnsen K, et al.; Czwarta Wspólna Grupa Robocza Europejskiego Towarzystwa Kardiologicznego i innych towarzystw do spraw prewencji chorób sercowo-naczyniowych w praktyce klinicznej. Europejskie wytyczne dotyczące prewencji chorób sercowo-naczyniowych w praktyce klinicznej - wersja skrócona. Kardiol Pol 2008; 66: 1-48.

7. Szponar L, Wolnicka, Rychlik E. Album fotografii produktów i potraw. İ̇ż, Warszawa 2008.

8. Piórecka B, Jagielski P, Żwirska J, Piskorz A, Brzostek T, Schlegel-Zawadzka M. Wpływ żywienia na występowanie wybranych metabolicznych czynników ryzyka chorób układu krążenia wśród mieszkańców Krakowa. Roczn PZH 2007; 58: 119-127.
9. Chabros E, Rogalska-Niedźwiecka M, Wajszczyk B, Chwojnowska Z, Kokosa J, Charzewska J. Styl życia kobiet 70-letnich, zbadanych w latach 1992 i 2002. Zdr Publ 2006; 116: 340-342.

10. Król E, Staniek H, Przybylska A, Krejpcio Z, Olejnik D. Charakterystyka wybranych aspektów sposobu żywienia pacjentów z chorobami układu krążenia na podstawie preferencji pokarmowych. Żywność Nauka Technologia Jakość 2006; 2: 162-170.

11. Pawelec M. Preferencje żywieniowe pacjentów Kliniki Kardiochirurgii PAM w Szczecinie. Ann UMCS 2005; 60 Suppl 16: 255-259.

12. Mędrela-Kuder E. Charakterystyka spożycia tłuszczów przez pacjentów podejmujących rehabilitację po przebytym zawale mięśnia sercowego. Brom Chem Toksykol 2009; 42: 678-682.

13. Waśkiewicz A, Piotrowski W, Sygnowska E i wsp. Jakość żywienia i wiedza zdrowotna osób po przebytych incydentach sercowo-naczyniowych w populacji polskiej - Wieloośrodkowe Ogólnopolskie Badanie Stanu Zdrowia Ludności WOBASZ. Kardiol Pol 2008; 66: 507-513.

14. Mojsa W, Snarska A. Analiza czynników psychospołecznych i zachowań zdrowotnych osób z chorobą niedokrwienną serca. Ann UMCS 2006; 60 Suppl. 16: 9-1.

15. Wierzbicka A. Zachowania zdrowotne pacjentów z dusznicą bolesną niestabilną. Ann UMCS 2003; 58 Suppl 13: 415-421.

16. Kłosiewicz-Latoszek L, Szostak W, Podolec P, et al. Epidemiologia i prewencja. Polish Forum for Prevention Guidelines on Diet. Kardiol Pol 2008; 66: 812-814.

17. Piotrowska R, Książek J. Styl życia z uwzględnieniem żywienia a występowanie zawału mięśnia sercowego na przykładzie pacjentów oddziału kardiologii. Ann UMCS 2005; 60 Suppl. 16: 361-365.

18. Suliburska J, Krejpcio Z, Bogdański P. Czy osoby dorosłe z nadciśnieniem tętniczym stosują dietę niskosodową? Brom Chem Toksykol 2008; 41: 695-698.

19. Zielińska-Więczkowska H, Wrońska I, Kędziora-Kornatowska K. Styl życia a potrzeba edukacji zdrowotnej chorych z pierwotnym nadciśnieniem tętniczym w wieku podeszłym. Zdr Publ 2003; 113: 160-163.

20. Suliburska J, Bogdański P, Chiniewicz M, Szulińska M. Ocena sposobu żywienia i stanu odżywienia pacjentów z pierwotnym nadciśnieniem tętniczym w aspekcie stosowanej farmakoterapii. Farm Współ 2010; 3: 5-10. 